\title{
The role of human ribosomal proteins in the maturation of rRNA and ribosome production
}

\author{
SARA ROBLEDO, ${ }^{1,3}$ RACHEL A. IDOL, ${ }^{1,3}$ DAN L. CRIMMINS, ${ }^{2}$ JACK H. LADENSON, ${ }^{2}$ \\ PHILIP J. MASON, ${ }^{1,4}$ and MONICA BESSLER ${ }^{1,4}$ \\ ${ }^{1}$ Department of Internal Medicine, Division of Hematology, Washington University School of Medicine, St. Louis, Missouri 63110, USA \\ ${ }^{2}$ Department of Pathology and Immunology, Division of Laboratory and Genomic Medicine, Washington University School of Medicine, \\ St. Louis, Missouri 63110, USA
}

\begin{abstract}
Production of ribosomes is a fundamental process that occurs in all dividing cells. It is a complex process consisting of the coordinated synthesis and assembly of four ribosomal RNAs (rRNA) with about 80 ribosomal proteins (r-proteins) involving more than 150 nonribosomal proteins and other factors. Diamond Blackfan anemia (DBA) is an inherited red cell aplasia caused by mutations in one of several r-proteins. How defects in r-proteins, essential for proliferation in all cells, lead to a human disease with a specific defect in red cell development is unknown. Here, we investigated the role of r-proteins in ribosome biogenesis in order to find out whether those mutated in DBA have any similarities. We depleted HeLa cells using siRNA for several individual r-proteins of the small (RPS6, RPS7, RPS15, RPS16, RPS17, RPS19, RPS24, RPS25, RPS28) or large subunit (RPL5, RPL7, RPL11, RPL14, RPL26, RPL35a) and studied the effect on rRNA processing and ribosome production. Depleting $r$-proteins in one of the subunits caused, with a few exceptions, a decrease in all r-proteins of the same subunit and a decrease in the corresponding subunit, fully assembled ribosomes, and polysomes. R-protein depletion, with a few exceptions, led to the accumulation of specific rRNA precursors, highlighting their individual roles in rRNA processing. Depletion of r-proteins mutated in DBA always compromised ribosome biogenesis while affecting either subunit and disturbing rRNA processing at different levels, indicating that the rate of ribosome production rather than a specific step in ribosome biogenesis is critical in patients with DBA.
\end{abstract}

Keywords: Diamond Blackfan anemia; ribosome biogenesis; siRNA; ribosome profile

\section{INTRODUCTION}

The production of ribosomes, the sites of protein synthesis, is a process of fundamental importance in cell biology. It has been estimated that in a rapidly growing yeast cell, the majority of transcription is devoted to ribosomal RNA (rRNA) and about half of RNA polymerase II transcription to ribosomal proteins (r-proteins) (Warner 1999). Tandem arrays of ribosomal genes are transcribed by RNA polymerase I in the nucleolus and the transcripts are cleaved, modified, and assembled with r-proteins to form the mature $40 \mathrm{~S}$ and $60 \mathrm{~S}$ subunits of the mature ribosome.

\footnotetext{
${ }^{3}$ These authors contributed equally to this work.

${ }^{4}$ Joint senior authors.

Reprint requests to: Philip J. Mason, Department of Internal Medicine, Division of Hematology, Washington University School of Medicine, 660 South Euclid Avenue, Campus Box 8118, St. Louis, MO 63110, USA; e-mail: pmason@im.wustl.edu; fax: (314) 362-8826.

Article published online ahead of print. Article and publication date are at http://www.rnajournal.org/cgi/doi/10.1261/rna.1132008.
}

Ribosome production in the nucleolus and export to the cytoplasm involve the coordinated synthesis of four rRNAs, about 80 r-proteins, more than 150 other proteins, and about 70 snoRNAs. The $60 \mathrm{~S}$ subunit contains $28 \mathrm{~S}, 5.8 \mathrm{~S}$, and 5S RNAs, while the 40S subunit contains 18S RNA. 5S RNA is transcribed by RNA polymerase III and imported into the nucleolus during ribosome maturation. Most of our knowledge about ribosome biogenesis derives from genetic studies in yeast and bacteria. While there is a high level of conservation between the components of ribosome biogenesis in yeast and mammalian cells, studies of mammalian ribosome production are still in their infancy.

Interest in mammalian ribosome biosynthesis has been stimulated by the finding that the pathogenesis of a number of inherited and acquired diseases involves mutations in genes encoding components of the ribosome or proteins involved in ribosome maturation, assembly, or export. Diamond Blackfan anemia (DBA, OMIM\#105650) is a rare inherited bone marrow failure syndrome that affects mainly 
the terminal stages of red cell differentiation (OheneAbuakwa et al. 2005; Lipton 2006). DBA is caused by mutations in one of several genetic loci, all of which code for r-proteins in both the small and large ribosomal subunit (Draptchinskaia et al. 1999; Willig et al. 1999; Gazda et al. 2006; Cmejla et al. 2007; Farrar et al. 2008; H. Gazda, pers. comm.). A major shift in our perception of the role of r-proteins came in 2000 when it was found that the catalytic molecule in ribosomes is rRNA and the r-proteins are likely to be responsible for the correct folding of rRNA, needed for accurate cleavage and processing, and for the assembly of the ribosome (Steitz and Moore 2003). The precise role of the 80 or so r-proteins in ribosome biogenesis is not fully understood, especially in mammals. In addition to their role in ribosome biogenesis, extraribosomal functions have been postulated for many of the r-proteins (Wool 1996).

DBA is usually diagnosed as a severe anemia in early childhood caused by a defect in red cell maturation (red cell aplasia). As well as failure of red cell development, the disorder may be associated with a variety of congenital abnormalities and a predisposition to malignancy (Lipton 2006). Mutations causing DBA have been found in RPS19 (accounting for 25\% of cases) (Draptchinskaia et al. 1999; Willig et al. 1999); RPS24 (2\%) (Gazda et al. 2006); RPS17 (one case) (Cmejla et al. 2007); RPL35a (2\%) (Farrar et al. 2008); and RPL5 and RPL11 (10\% each) (H. Gazda, pers. comm.). In all cases the inheritance is autosomal dominant; haploinsufficiency for the r-protein is thought to be the mechanism of disease (Gazda et al. 2004). However, the mechanism whereby haploinsufficiency for one of several r-proteins leads specifically to red cell aplasia while only minimally affecting other tissues is unknown. Mice heterozygous for an Rps19 gene deletion develop normally with no abnormalities in red cell development (Matsson et al. 2004, 2006). In contrast, cell culture studies using bone marrow cells or peripheral blood hematopoietic progenitor cells from patients with DBA show that the defect is intrinsic to the red cell progenitors, which fail to complete differentiation in response to erythropoietin (OheneAbuakwa et al. 2005). Depleting the amount of RPS19 in human $\mathrm{CD} 34^{+}$primitive hematopoietic progenitors causes a reduction in the proliferation of immature red cells (Ebert et al. 2005; Flygare et al. 2005). It has recently been shown that the depletion of RPS19 in human cell lines by siRNA causes decreased ribosome synthesis with accumulation of some specific rRNA precursors (Choesmel et al. 2007; Flygare et al. 2007; Idol et al. 2007). The same precursors were found to accumulate to some extent in patients' fibroblasts, lymphocyte cell lines, and, in one case, in primary cells from bone marrow (Flygare et al. 2007). Similarly, depletion of RPS24 causes decreased rRNA synthesis due to failure of an earlier step in 18S rRNA processing (Choesmel et al. 2008). Since the only known genetic cause of DBA is mutations in genes coding for r-proteins, we were interested to test whether the possible molecular mechanism would be a specific defect in the synthesis of ribosomes shared by the r-proteins affected in DBA.

To investigate this hypothesis and to gain insight into the molecular mechanism responsible for disease, we depleted HeLa cells for the mRNA coding for a selection of r-proteins, including several known to be involved in DBA pathogenesis. We found that depletion of r-proteins involved in the pathogenesis of DBA may affect either subunit, but always was associated with a decrease in the production of ribosomes. We further found that depletion of any r-proteins involved in the pathogenesis of DBA also decreased the amount of all r-proteins from the same subunit, and caused a decreased production of the corresponding subunit. The alterations in rRNA processing varied amongst the various DBA-associated r-proteins and did not correlate with disease association. We therefore conclude that any of the r-proteins, when mutated, compromise ribosome biogenesis, is a potential candidate for DBA, and that the common factor is the decreased production of ribosomes rather than a specific step in ribosome biogenesis or the accumulation of a specific rRNA or ribosome subunit precursor.

\section{RESULTS}

In order to investigate whether there are common features in the function of r-proteins mutated in DBA, we investigated the role of $15 \mathrm{r}$-proteins in ribosome biosynthesis and rRNA processing, including six r-proteins that are currently known to be affected in DBA. At the time the study was initiated, only r-proteins of the small subunit RPS19 (Draptchinskaia et al. 1999), RPS24 (Gazda et al. 2006), and RPS17 (Cmejla et al. 2007) were known to be mutated in DBA. During the course of the study, the number of r-proteins responsible for DBA increased, including proteins belonging to the large r-subunit, RPL35a (Farrar et al. 2008), and RPL5 and RPL11 (H. Gazda, pers. comm.).

\section{Depletion of r-protein mRNAs in HeLa cells using siRNA}

We and others have previously reported on the effect of r-protein RPS19 depletion on ribosome biosynthesis and rRNA processing. Here, we used a similar approach depleting individual r-proteins in growing HeLa cells using siRNA. In addition to the proteins RPS17, RPS19, RPS24, RPL5, RPL11, and RPL35a known to be associated with DBA, we also studied the depletion of RPS6, RPS7, RPS15, RPS16, RPS25, RPS28, RPL7, RPL14, and RPL26. To date, these r-proteins have not been associated with DBA, but their involvement is not ruled out, as the causative mutation has not been found in about half of the known DBA patients. The efficiency of r-protein depletion was assessed by Western blotting using either commercially 
available or in-house antibodies and by Northern analysis using cDNA probes.

Figure 1 is an example of the data showing the depletion of mRNA for the r-proteins in our study. In all cases, the siRNA reduces the abundance of the mRNA to almost undetectable levels. The percentage knockdowns shown in Figure 1 are those from one typical experiment obtained from phosphorimaging of Northern blots. Notably, the target mRNA was the only one that was decreased in abundance. No evidence for reduction in one mRNA causing consistent and significant reduction in any of the others was found.

\section{Depletion of r-proteins causes decreased abundance of other r-proteins belonging to the same ribosomal subunit}

We next examined the effect of the mRNA knockdown on the steady-state level of r-proteins. Protein was extracted from the cells $72 \mathrm{~h}$ after the cells had been transfected with the siRNAs, and r-proteins were examined by Western blotting (Fig. 2). For this we generated peptide antibodies for RPS7, RPS12, RPS15, RPS24, RPS25, and RPS28. We have previously reported the generation of peptide antibodies against RPS19. Antibodies against RPS6, RPS16,
RPL7, and RPL26 were from commercial sources. Western analysis showed that the steady-state level of the siRNA targeted r-protein was decreased by $30 \%-60 \%$ (Fig. 2). In several experiments, there was considerable variation in the level of protein knockdown achieved. The knockdown of one of the r-proteins always resulted in a decrease of the steady-state levels of the other r-proteins belonging to the same ribosomal subunit (Fig. 2). The exception to this was RPS25. When RPS25 mRNA was reduced in abundance to almost zero, RPS6, RPS12, RPS16, RPS19, and RPS24 did not significantly change in abundance. Using an antibody to RPS25 shows that cells treated with siRNA to RPS25 were indeed depleted for RPS 25 and that no reduction in the steady-state level of any of the other r-protein of the small subunit (RPS) proteins was apparent. For r-proteins belonging to the large ribosomal subunit, RPL7, RPL14, RPL26, and RPL35a (RPLs), we used antibodies against RPL7 and RPL26. Figure 2 shows that, as expected, there was a reduction in the steady-state levels of RPL7 and RPL26 when the level of their mRNAs was reduced. In keeping with our results from the RPS knockdowns, the levels of RPL7 and RPL26 proteins were reduced to a similar extent when RPL5, RPL7, RPL11, RPL14, or RPL35a were knocked down. Interestingly, though RPS19 was unaffected by depletion of RPL5, RPL7, RPL11, RPL14, or RPL35a, depletion of RPL26 caused an approximate $30 \%$ reduction in
A

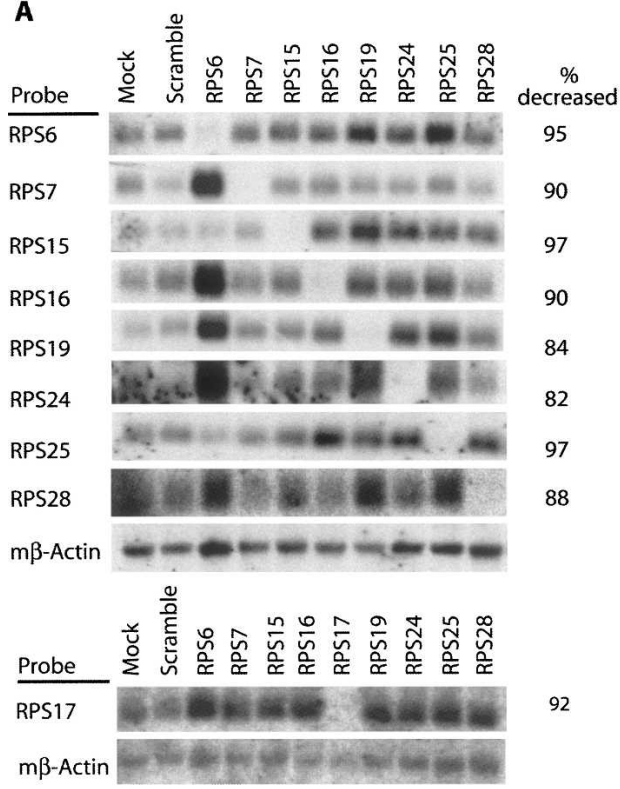

B

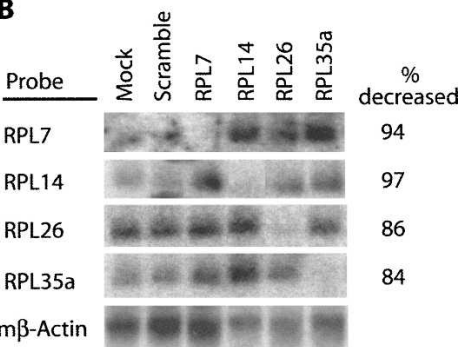

RPS19 level. Depletion of the RPS proteins had no effect on the levels of RPL26.

\section{Depletion of r-proteins causes decreased production of mature ribosomes and functionally active polysomes}

We next investigated the effect of the depletion of individual r-proteins on the ribosome profile in the HeLa cells $72 \mathrm{~h}$ after siRNA treatment. HeLa cells that were mock transfected showed a classical profile of ribosomes and polysomes, with the $40 \mathrm{~S}$ and $60 \mathrm{~S}$ ribosomal subunits and a large $80 \mathrm{~S}$ peak representing the mature assembled ribosome (monosome). Depletion of any of the RPSs caused a reduction in the amount of free $40 \mathrm{~S}$ subunits, a great reduction in the amount of mature $80 \mathrm{~S}$ ribosomes, and an increase in the amount of free 60 S subunits (Fig. 3). The exception was again RPS25. Here, the ribosome profile showed an intermediate phenotype with a reduction in the amount of $80 \mathrm{~S}$ ribosomes and an increase in the amount of 
A

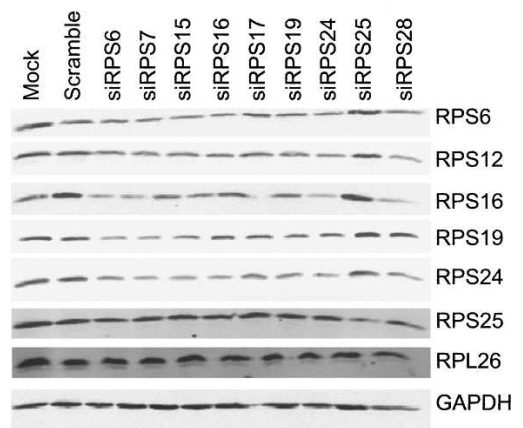

B

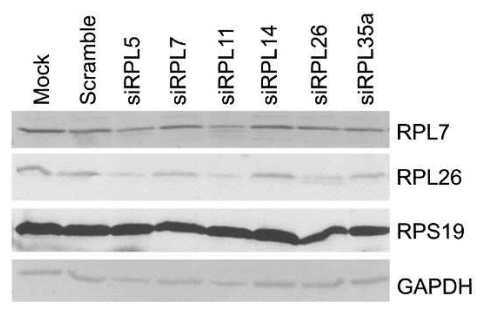

FIGURE 2. Knocking down ribosomal proteins decreases the levels of other ribosomal proteins of the same subunit. Western blot analysis of r-protein levels after siRNA treatment. Total cellular protein was extracted $72 \mathrm{~h}$ after treatment with siRNA specific to each target or a scrambled sequence. $(A)$ Western blotting was performed to examine the levels of RPS6, RPS12, RPS16, RPS19, RPS24, RPS25, RPL26; GAPDH was used as a loading control. Knocking down all RPS proteins analyzed decreased the levels of other RPS proteins, with the exception of RPS25. RPS25 protein levels were decreased by treatment with siRNA against RPS25, although the levels of the other r-proteins of the small subunit examined did not change. The levels of RPL proteins did not decrease. (B) Western blot analysis of RPL7, RPL26, and RPS19 protein levels after depletion of RPL proteins; GAPDH was used as a loading control. Knocking down all RPL proteins analyzed decreased the levels of other RPL proteins. The levels of r-proteins of the small subunit did not decrease, except in the RPL26 knockdown where a slight reduction of RPS19 levels was observed.

$60 \mathrm{~S}$ subunits, but no significant changes in the amount of the $40 \mathrm{~S}$ subunit. In the polysome region of the profiles, we note a variation in the extent to which polysomes are decreased with a trend toward a decrease in the relative number of large polysomes, perhaps reflecting a decrease in the number of initiations caused by the deficiency in the number of $40 \mathrm{~S}$ subunits. A somewhat different pattern was seen when RPLs were depleted (Fig. 3). In the case of RPL5, RPL7, RPL11, RPL14, RPL26, and RPL35a depletion compared with the normal ribosome profile, the amount of the $60 \mathrm{~S}$ subunit was greatly reduced, as was the peak representing the levels of $80 \mathrm{~S}$ ribosomes. There was a concomitant increase in the amount of free $40 \mathrm{~S}$ subunit, although for the RPL26 depletion the free 40S subunit did not show this increase. In these profiles, the $80 \mathrm{~S}$ and polysome peaks are split, an appearance characteristic of "halfmers," which are monosomes and polysomes to which an isolated 40S subunit is bound (Helser et al. 1981). In the
RPL knockdowns, there appears to be a decrease in the overall number of polysomes.

\section{Depletion of r-proteins blocks rRNA processing at specific steps}

The r-proteins not only serve as a scaffold for the rRNA and ensure the correct structure of the ribosome, but are also involved in the maturation of the rRNA precursors. Having found that depleting any r-protein decreases the production of one ribosomal subunit and, consequently, production of mature ribosomes, we were interested to know the effect of each depletion on pre-rRNA processing. Since ribosome biogenesis involves a characteristic series of rRNA processing events, we can investigate the extent, and at which level, pre-rRNA processing is affected by the depletion of individual r-proteins. RNA was extracted from HeLa cells $72 \mathrm{~h}$ after the cells had been transfected with the various siRNAs. The RNA was subjected to Northern blotting using a series of probes from within the rRNA
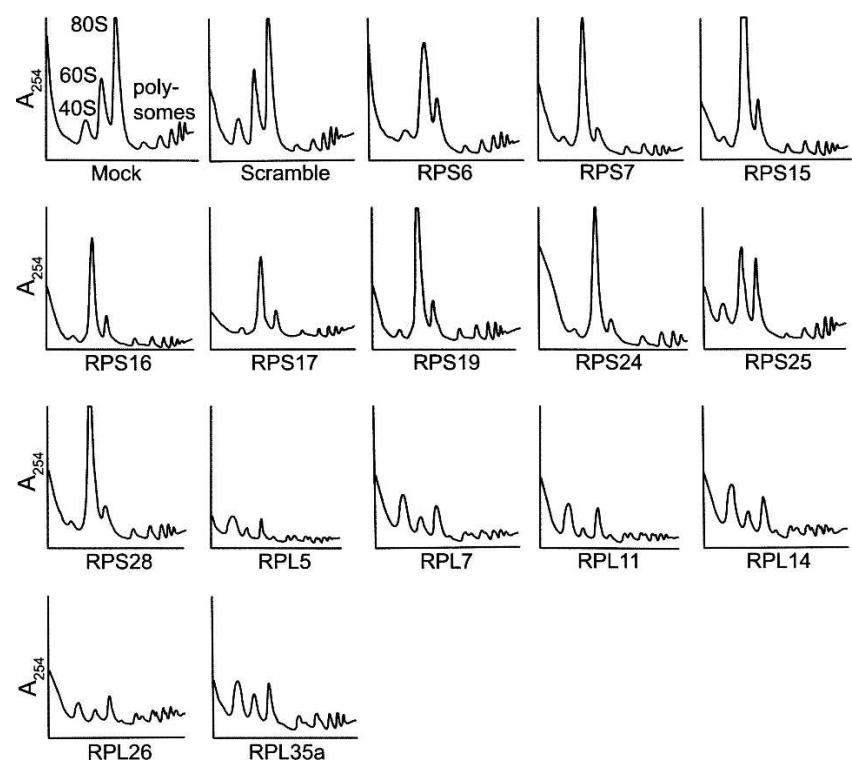

FIGURE 3. Depletion of r-proteins impairs the synthesis of new ribosomes. After $72 \mathrm{~h}$ of treatment with siRNA, cells were treated with cycloheximide, lysed, and the cytoplasmic fraction was layered over $10 \%-45 \%$ sucrose gradients. Mock or scramble treated cells show a typical profile of free $40 \mathrm{~S}$, free $60 \mathrm{~S}, 80 \mathrm{~S}$, and polysomes. Cells depleted for RPS6, RPS7, RPS15, RPS16, RPS17, RPS19, RPS24, and RPS28 have significantly decreased levels of free $40 \mathrm{~S}$ and $80 \mathrm{~S}$, with a dramatic increase in free 60S. The polysome levels are decreased. RPS25 depleted cells show an intermediate phenotype, with a slight decrease in free 40S, an increase in free 60S, and partial decrease in $80 \mathrm{~S}$. Depleting cells of RPL5, RPL7, RPL11, RPL14, and RPL35a show an increase in free $40 \mathrm{~S}$ subunits, a substantial decrease in free $60 \mathrm{~S}$ subunits, and a decrease in the $80 \mathrm{~S}$. Polysome profiles also demonstrate the presence of halfmers and a decrease in polysomes, particularly the larger polysomes. Depletion of RPL26 also decreased the free $60 \mathrm{~S}$ subunit and the $80 \mathrm{~S}$ and produced halfmer polysomes, although the free $40 \mathrm{~S}$ levels did not increase as dramatically as was seen with other RPL knockdowns. 
locus. The location of the probes and the rRNA processing pathway as it is thought to occur in HeLa cells (Hadjiolova et al. 1993) is schematically shown in Figure 4A. Figure 4B shows the effects on pre-rRNA processing of the depletion of $r$-proteins of the small subunit. Depletion of RPSs affected the formation of the mature 18S rRNA, while the formation of the mature $28 \mathrm{~S}$ and 5.8S RNA was not significantly affected (Fig. 5; data not shown). The defects in rRNA processing detected by Northern blotting after the depletion of individual r-proteins of the small subunit fell into three district categories. The most frequently observed defect in pre-rRNA processing, seen after depleting RPS6, RPS7, RPS16, RPS24, and RPS28, was characterized by the decrease of the 41S rRNA precursor and an accumulation of a $30 \mathrm{~S}$ rRNA processing intermediate, and a decrease in the 21S and 18SE precursors. This implies that the respective $r$-proteins are essential for the processing at the 5 '-ETS, which leads to the decrease in the 41S, the accumulation of the $30 \mathrm{~S}$ precursor, and a decrease of the $21 \mathrm{~S}$ r-RNA and 18S-E precursors. For RPS24, similar findings were reported by Choesmel et al. (2008). A different pre-rRNA processing defect was observed for RPS17 and RPS19 depletion, which caused accumulation of the $21 \mathrm{~S}$ and $20 \mathrm{~S}$ precursors, implying that these two r-proteins are required for a later step in pre-rRNA processing during which the $21 \mathrm{~S}$ molecule is processed to form the 18S-E nuclear precursor. The third defect is shown after the depletion of RPS15 and also after depletion of RPS25. Here, all the rRNA precursors are present at levels similar to those in untreated cells or cells treated with the scrambled control siRNA, and 18S-E is exported into the cytoplasm in both cases. Interestingly, results from the ribosome profiles obtained from RPS15-depleted cells show that the production of $40 \mathrm{~S}$ subunits is defective in these cells, whereas in RPS25-depleted cells the production of the $40 \mathrm{~S}$ subunit is only impaired, leading us to conclude that RPS15 may play a role late in

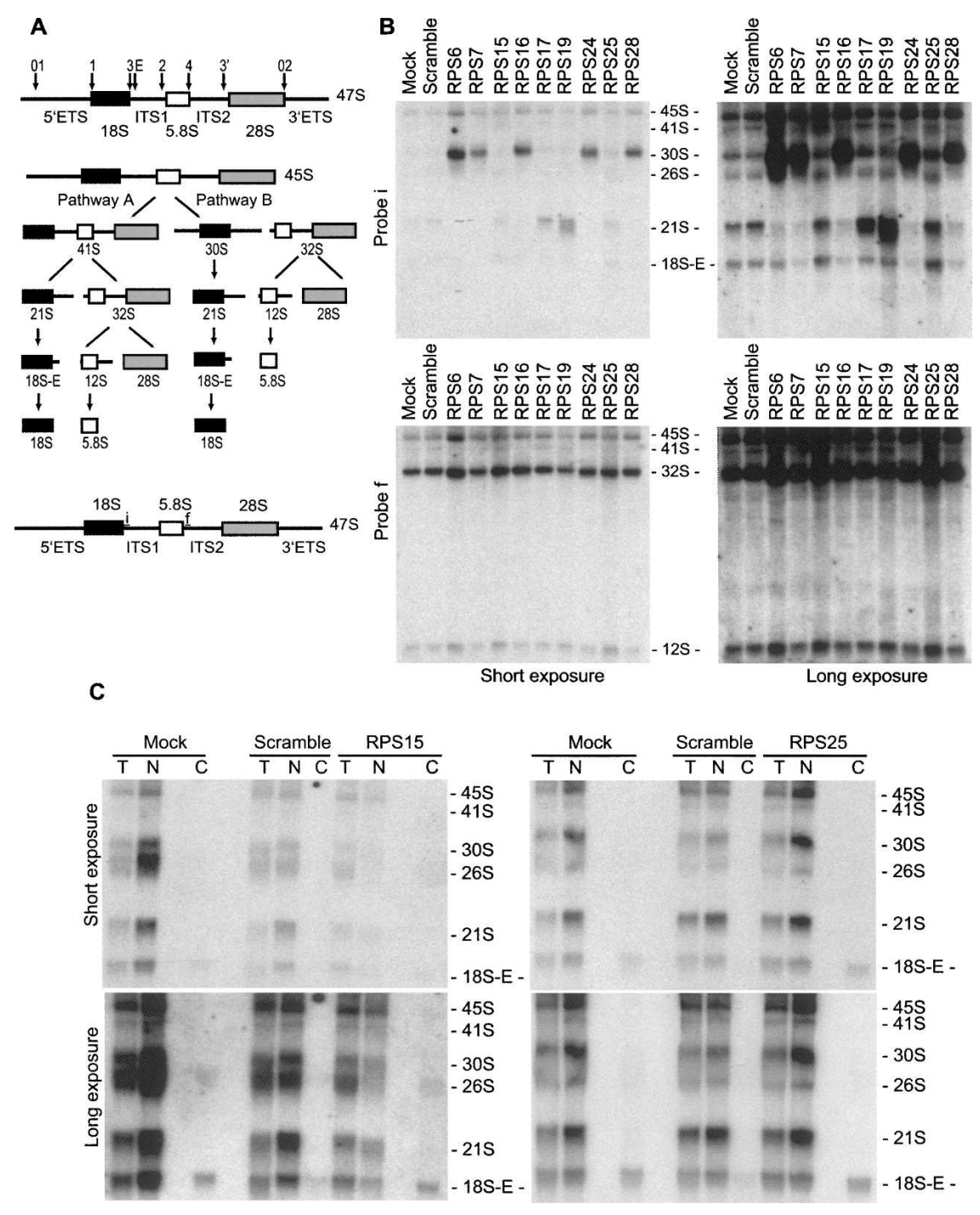

FIGURE 4. Ribosomal proteins of the small subunit control distinct rRNA processing steps important for the maturation of the $18 \mathrm{~S}$ rRNA. (A) Schematic diagram of pre-rRNA processing pathways in HeLa cells. (Inset) Structure of the primary 47S rRNA transcript containing two external transcriber spacers at its $5^{\prime}$ and $3^{\prime}$ ends (5'ETS and $3^{\prime}$ ETS, respectively), as well two internal transcriber spacers (ITS1 and ITS2). (Arrows) Position of major processing sites $(0-4)$. The $47 \mathrm{~S}$ pre-rRNA is processed through intermediate precursors designated according to their relative sedimentation coefficients $(\mathrm{S})$ to mature $18 \mathrm{~S}, 28 \mathrm{~S}$, and 5.8S rRNAs. In HeLa cells, 45S pre-rRNA can be processed by two alternative pathways. Pathway A is initiated with the removal of $5^{\prime}$-ETS by cleavage at site 1 , while pathway B starts with cleavage in ITS1, probably at site 2 (Hadjiolova et al. 1993; Rouquette et al. 2005; Idol et al. 2007). The sequence locations of the probes used in Northern blot analysis are shown as a line above the primary transcript scheme (bottom). (B) Northern hybridization of total RNA from HeLa cells after depletion of r-proteins of the small subunit. Cells were transfected with scrambled negative control siRNA or siRNAs targeting RPS6, RPS7, RPS15, RPS16, RPS17, RPS19, RPS24, RPS25, or RPS28 mRNAs. After $72 \mathrm{~h}$, total RNA was extracted and subjected to Northern blotting analysis for pre-rRNA species. Membranes were hybridized with probes for the $5^{\prime}$ end of ITS1 (probe i, upper panel), $5^{\prime}$ ends of ITS2 (probe f, lower panel), or $\beta$-actin. (Left panel) Short exposure, (right panel) long exposure. Depletion of r-proteins of the small subunit block rRNA processing at specific steps. The sizes of pre-rRNA species are indicated between the left and right panels. $(C)$ Northern hybridization of total $(\mathrm{T})$, nuclear $(\mathrm{N})$, and cytoplasmic (C) rRNA isolated from HeLa cells after depletion of r-proteins of RPS15 and RPS25. Cells were transfected with scrambled negative control siRNA or siRNAs targeting RPS15 and RPS25 mRNAs. Membranes were hybridized with probes for the 5' end of ITS1 (probe i). 


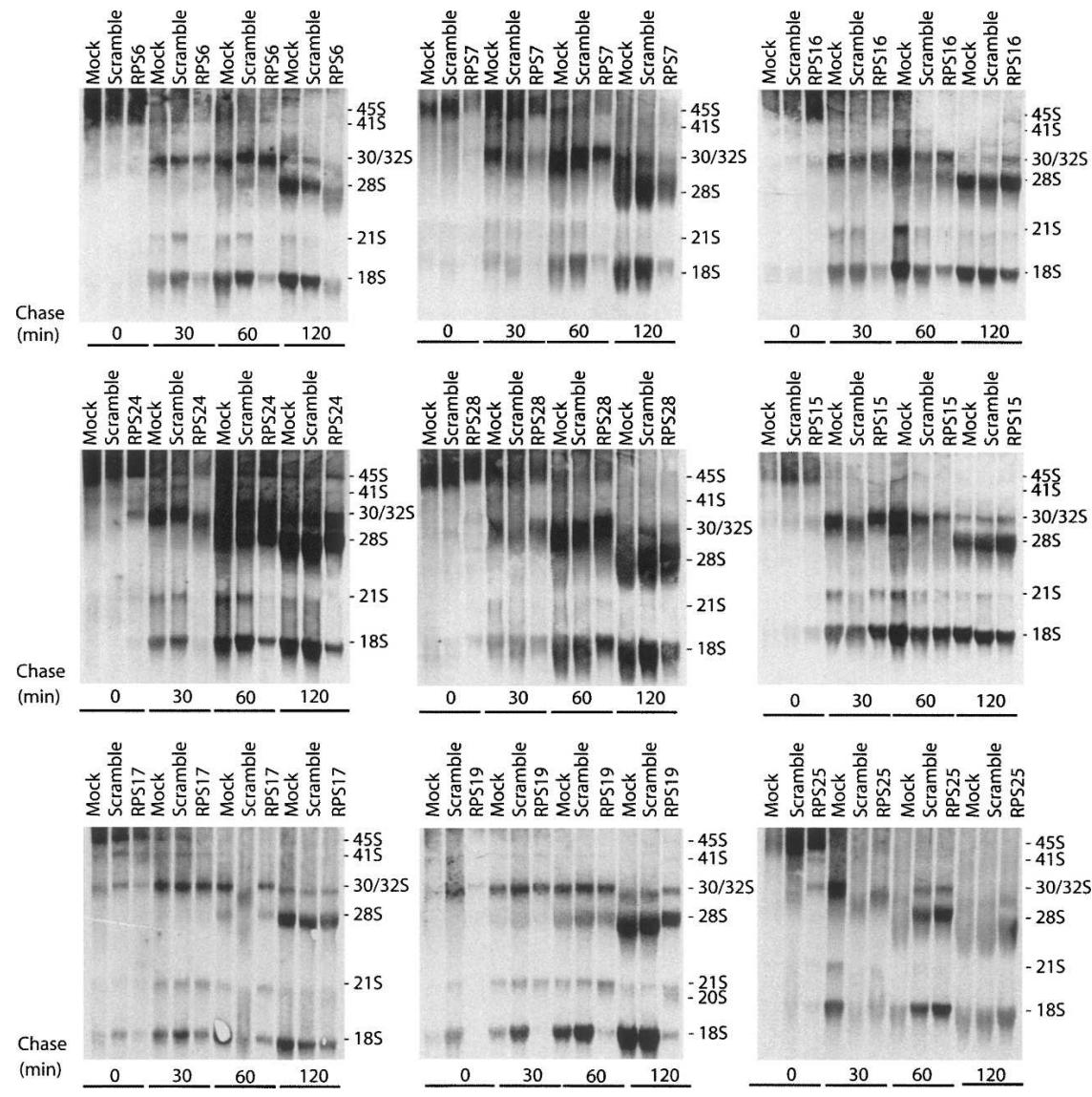

FIGURE 5. Impaired $18 \mathrm{~S}$ rRNA synthesis in HeLa cells depleted of r-proteins of the small subunit. Cells were transfected with scrambled negative control siRNA or siRNAs targeting RPS6, RPS7, RPS15, RPS16, RPS17, RPS19, RPS24, RPS25, or RPS28 mRNAs. After $72 \mathrm{~h}$, cells were pulsed with $\mathrm{L}-\left[\right.$ methyl $\left.{ }^{3} \mathrm{H}\right]$ methionine and then chased at $0,30,60$, and $120 \mathrm{~min}$. Total rRNA was extracted after labeling and analyzed by fluorography.

ribosome biogenesis involving the final stages of maturation in the cytoplasm or interaction with the large subunit, whereas RPS25 is not essential for 40S subunit production. Metabolic labeling of cells with ${ }^{3} \mathrm{H}$-methylmethionine after depletion of r-proteins of the small subunit similarly confirmed the decrease in the production of the mature $18 \mathrm{~S}$ rRNA, while $28 \mathrm{~S}$ rRNA was not affected. This was the case in all knockdown cells with the exception of RPS15 and RPS25 depleted cells, which seemed to synthesize both the $18 \mathrm{~S}$ and $28 \mathrm{~S}$ rRNA and all precursors at a level and rate that were indistinguishable from normal or mock transfected cells (Fig. 5).

Northern blotting studies with knockdowns of RPLs (Fig. 6A) showed that depletion of all six RPLs tested, comprising RPL7, RPL14, RPL26, RPL35a, RPL5, and RPL11, led to reduced levels of the mature $28 \mathrm{~S}$ rRNA. RPL7, RPL14, and to a lesser extent RPL26 depletion showed an accumulation of the $45 \mathrm{~S}$ and $41 \mathrm{~S}$ early precursor RNAs. Cells depleted for RPL7, RPL14, RPL26, and RPL35a also had reduced levels of the $12 \mathrm{~S}$ precursor rRNA and the mature 5.8S rRNA, whereas in RPL5 and RPL11 depletions the 12S rRNA precursor accumulated (Fig. 6A). Metabolic labeling studies (Fig. 6B) showed all six RPL knockdowns led to greatly decreased $28 \mathrm{~S}$ synthesis. Interestingly, depletion of RPL26 also led to significantly decreased levels of the $21 \mathrm{~S}$ and 18S-E rRNA, whereas that of RPL35a led to slightly decreased levels of the $30 \mathrm{~S}$ and $21 \mathrm{~S}$ rRNA precursors as shown by Northern blotting (Fig. 6A). RPL26 depletion led to lower and slower production of 18S RNA (Fig. 6B). These data indicate that these two RPLs also affect the processing and cleavage of the $45 \mathrm{~S}$ pre-RNA at the $5^{\prime}$-ETS (site 01 and 1) and ITS1 (site 2 and E).

\section{DISCUSSION}

Ribosomal protein genes have been found to be the genes mutated in patients with DBA, a rare inherited form of red cell aplasia. So far, three genes encoding RPSs: RPS19, (Draptchinskaia et al. 1999; Willig et al. 1999), RPS17 (Cmejla et al. 2007), and RPS24 (Gazda et al. 2006), and three genes encoding RPLs: RPL5, RPL11 (H. Gazda, pers. comm.), and RPL35a (Farrar et al. 2008) have been found to be mutated. In about one-half of the patients, these are de novo mutations occurring for the first time in the affected individual, whereas in about one-half of patients the mutations are inherited. Mutations include gene deletions and frameshift mutations, suggesting that haploinsufficency for the r-protein is the cause of the dominantly inherited disease (Gazda et al. 2004). The number of DBA families with mutations in the genes varies, with RPS19 accounting for one-fourth of families and RPL 5 and RPL11 each accounting for $\sim 10 \%$ of patients; whereas RPS24, RPS17, and RPL35a only account for a small number of patients with DBA (Cmejla et al. 2007; Farrar et al. 2008; H. Gazda, pers. comm.). For more than half of the patients with DBA the mutation has not yet been identified, and not all r-proteins have been screened for disease causing mutations. Here, we examined whether the r-proteins affected in DBA share a common pathway in ribosome biogenesis and/or pre-RNA processing that would explain why a defect that potentially affects all dividing cells manifests itself as a disease of such exquisite tissue and lineage specificity. Interestingly, depletion of the affected r-proteins in HeLa cells using siRNA showed that 


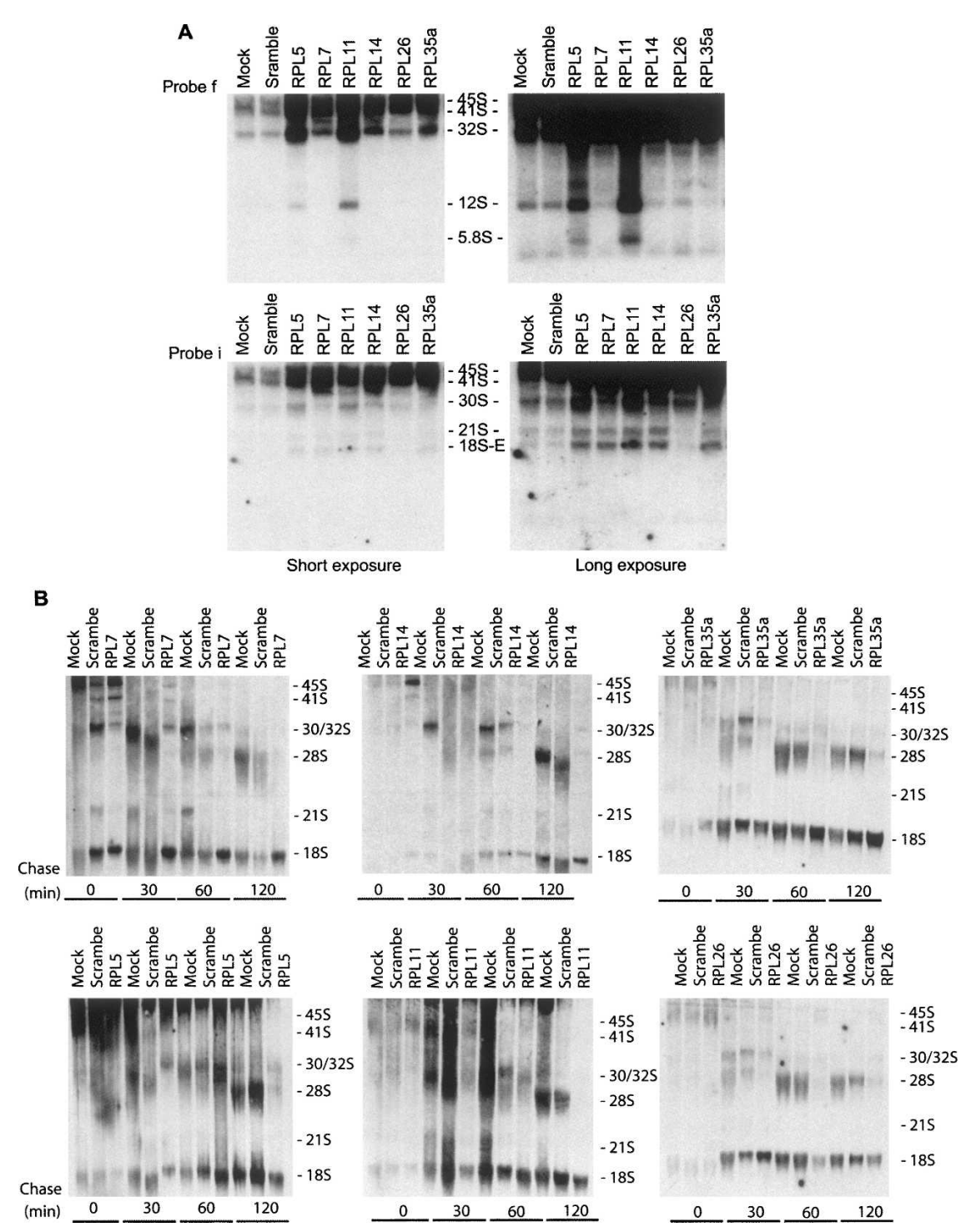

FIGURE 6. Ribosomal proteins of the large subunit control distinct rRNA processing steps, in particular, those important for the maturation of the $28 \mathrm{~S}$ rRNA and 5.8S rRNA. (A) Northern hybridization of total RNA from HeLa cells after depletion of r-proteins of the large subunit. Cells were transfected with scrambled negative control siRNA or siRNAs targeting RPL5, RPL7, $R P L 11$, RPL14, RPL26, or RPL35a mRNAs. After $72 \mathrm{~h}$, total RNA was extracted and subjected to Northern blotting analysis for pre-rRNA species. Membranes were hybridized with probes for the $5^{\prime}$ end of ITS1 (probe i, upper panel) and 5' end of ITS2 (probe f, lower panel). PrerRNA products after hybridization with probe i (upper panel) and probe $\mathrm{f}$ (lower panel). (Left panel) Short exposure, (right panel) long exposure. The sizes of pre-rRNA species are indicated between the left and right panels. This short run is shown to emphasize the characteristic difference in $5.8 \mathrm{~S}$ and $12 \mathrm{~S}$ accumulation. (B) Analysis of the rRNA synthesis of $18 \mathrm{~S}$ and $28 \mathrm{~S}$ in HeLa cells depleted of r-proteins of the large subunit by pulse-chase analysis with L$\left[\right.$ methyl $\left.{ }^{3} \mathrm{H}\right]$ methionine labeling. Cells were transfected with scrambled negative control siRNA or siRNAs targeting RPL5, RPL7, RPL11, RPL14, RL26, or RPL35a mRNAs. After $72 \mathrm{~h}$, cells were pulsed with $\mathrm{L}$ - $\left[\right.$ methyl $\left.{ }^{3} \mathrm{H}\right]$ methionine and then chased at $0,30,60$, and $120 \mathrm{~min}$. Total rRNA was extracted after labeling and analyzed by fluorography.

the only shared feature was that their depletion impaired the production of ribosomes, as assayed by examination of the ribosome profile on sucrose gradients, a characteristic we found to be shared with most, although not all, other r-proteins. Furthermore, our results demonstrated that the depletion of r-proteins associated with DBA could affect the biosynthesis of either the large or small ribosomal subunit. Finally, we found that pre-RNA cleavage was impaired at various steps of rRNA processing, leading to the accumulation of different rRNA precursors. Interestingly, RPS19, RPL5, and RPL11, which account for almost $35 \%$ of cases of DBA, show defects in late nucleolar maturation of the pre-40S and pre-60S ribosomal particles.

With the exception of RPS25 and RPS15, depletion of RPSs always led to decreased levels of mature 18S rRNA, decreased levels of the small $40 \mathrm{~S}$ ribosomal subunit, and decreased levels of mature 80 S ribosomes. RPS15 did not visibly affect rRNA processing, export of the 18S-E RNA precursor, or the accumulation of the mature 18S RNA in metabolic labeling experiments. However, the levels of $40 \mathrm{~S}$ ribosomal subunits and $80 \mathrm{~S}$ ribosomes were decreased, indicating that RPS15 is essential for a late maturation step of the 40S subunit. In contrast, RPS25 seemed to have no effect on rRNA processing, 18S-E export, or mature $18 \mathrm{~S}$ rRNA accumulation, and was not essential for $40 \mathrm{~S}$ and $80 \mathrm{~S}$ ribosome biosynthesis, though formation of small subunits was reduced in its absence. In all of these cases, impairment of the formation of the small ribosome subunit did not affect the maturation of the 28S and 5.8S rRNA and was associated with excess production of the 60S large subunit.

Ribosome biogenesis has been studied extensively in yeast. Several recent studies have documented the role in ribosome biogenesis of specific r-proteins by depleting proteins using the power and elegance of yeast genetics (van Beekvelt et al. 2001; Leger-Silvestre et al. 2004, 2005; West et al. 2005; Ferreira-Cerca et al. 2007; Rosado et al. 2007). In both human and yeast, RPS6, RPS16, and RPS24 depletion all impair the processing of the $5^{\prime}$ ETS, leading to the accumulation of an early precursor and decrease of the $20 \mathrm{~S}$ (yeast) 21S (human) rRNA molecule that is a precursor to $18 \mathrm{~S}$ rRNA. Similarly in both yeast and human, RPS19 
depletion leads to the accumulation of the 20S/21S rRNA species, which is not processed further. Finally, in both yeast and humans, RPS25 was not essential for ribosome biosynthesis. However, we also identified distinct differences in the role of r-proteins in humans and yeast. In contrast to yeast, in HeLa cells the ribosome profile was altered after the depletion of RPS25 (see Fig. 3), suggesting that the depletion of RPS25 allows the assembly of the 40S subunit but impairs its association with the 60S subunit to form the mature $80 \mathrm{~S}$ ribosome or that the $80 \mathrm{~S}$ ribosome is unstable and is degraded. Furthermore, we found that RPS15 depletion in human cell lines did not visibly impair the processing of the rRNA, and that the 18S-E rRNA precursor was exported into the cytoplasm as in mock transfected cells or cells transfected with a scrambled siRNA. However, the levels of $40 \mathrm{~S}$ subunit and $80 \mathrm{~S}$ mature ribosomes were greatly reduced, suggesting that in humans RPS15 is essential for the final cytoplasmic maturation and assembly of the $40 \mathrm{~S}$ subunit. In contrast, in yeast, depletion of RPS15 leads to the accumulation of the $20 \mathrm{~S}$ in the nucleus, suggesting that RPS15 in yeast is essential for export from the nucleus (Leger-Silvestre et al. 2004). Finally, in HeLa cells, the depletion of RPS7 and RPS28 led to the accumulation of the early $30 \mathrm{~S}$ rRNA precursor, whereas in yeast, RPS7 and RPS28 affect the cytoplasmic maturation of the $18 \mathrm{~S}$ rRNA and terminal assembly of the $40 \mathrm{~S}$ subunit. The defect in HeLa cells was assessed for at least two independent siRNAs for each r-protein, indicating that off-target effects were unlikely to account for the differences observed. RPS17 depletion was not analyzed in yeast. Further analysis will show whether these are real differences in the yeast and human r-proteins and when in evolution these proteins might have adopted a different role in ribosome biogenesis.

Depletion of RPLs similarly primarily affected production of the mature $28 \mathrm{~S}$ and $5.8 \mathrm{~S}$ rRNA, the assembly of the $60 \mathrm{~S}$ large ribosomal subunit, the mature $80 \mathrm{~S}$ ribosome, and led to the production of "halfmers," due to the binding of a $40 \mathrm{~S}$ subunit to a mRNA without a $60 \mathrm{~S}$ subunit. The exception was the depletion of RPL26 that impaired both the production of the mature $18 \mathrm{~S}$ and $28 \mathrm{~S}$ rRNA with a reduction of both the $40 \mathrm{~S}$ and $60 \mathrm{~S}$ subunits, a reduction of the $80 \mathrm{~S}$ mature ribosome, and the generation of halfmers. RPLs associated with DBA showed defects in either early or late processing of the $28 \mathrm{~S}$ and $5.8 \mathrm{~S}$ rRNA, whereas the most frequent forms of RPL mutations in DBA, RPL5, and RPL11 affected the late steps in 28S and 5.8S maturation occurring in the nucleolus. In contrast to RPSs, RPLs have not been studied in a systematic manner in yeast; thus, a comparison of the role of RPLs in ribosome biogenesis in yeast and humans is not possible. Interestingly, RPL5 and RPL11 share two other properties as well as their connection with DBA. Both have been implicated in negatively regulating MDM2, a nucleolar protein that causes rapid turnover of the oncoprotein p53 (Marechal et al. 1994;
Lohrum et al. 2003; Zhang et al. 2003). Moreover, both are associated, at least in yeast, with $5 \mathrm{~S}$ rRNA at an early stage in ribosome biogenesis (Zhang et al. 2007).

One of the most interesting observations of our study is that depleting a cell of a r-protein leads not only to a decrease in the abundance of that protein as expected but also to a concomitant decrease in the abundance of all proteins from the same subunit. The most likely explanation for this observation is that the lack of one r-protein prevents formation of a stable subunit, and other proteins of that subunit with no structure to be incorporated into are degraded. This explanation is compatible with early results that showed excess ribosomal proteins, which are not assembled into ribosomes, are rapidly degraded (Warner 1977, 1979). This point has been reinforced by a recent study showing that $r$-proteins are synthesized at rates much higher than required for ribosome biogenesis, and that excess proteins not incorporated into ribosomes are rapidly degraded in the nucleoplasm (Lam et al. 2007). As pointed out by Lam et al., this suggests a simple way for the cell to solve the problem of coordinated synthesis of r-proteins for ribosome production; i.e., they are simply made in vast excess, and those not needed are degraded. In the experiments presented here, when one protein becomes limiting there is a rapid decrease in the other proteins of that subunit. We observe this concerted decrease in proteins of one subunit for all the knockdowns we have carried out except for that of RPS25. Alternatively, when one r-protein is under-produced, there may be some assembly of other proteins into nascent subunits followed by partial disassembly and turnover in the absence of stoichiometric amounts of ribosomal components (Moritz et al. 1990). This scheme may be more compatible with the decrease in r-proteins and accumulation of rRNA precursors that we observe.

To what extent are our observations relevant to the pathogenesis of DBA? At first glance there is a conundrum since, if $r$-proteins are made in vast excess over requirements, then reducing the production of an r-protein by $50 \%$ as happens in DBA should not have a drastic effect. We must therefore hypothesize that in developing red cells, and possibly in cells of other tissues affected in DBA, there is a requirement for maximal ribosome synthesis at a time when DNA transcription is turned off as part of erythroid maturation or in a key developmental stage elsewhere. Erythroid precursors in response to erythropoietin do indeed have a very high rate of ribosome production in order to undergo the final red cell divisions and to be able to produce the massive amounts of globin needed in the mature circulating red cell (Rifkind et al. 1964; Flygare and Karlsson 2007). If the rate of ribosome production required was more than half of the maximum rate governed by production of r-proteins, then haploinsufficiency for any r-protein would slow ribosome production. In red cell maturation, this may lead to the cell cycle arrest or cell 
death that is the hallmark of DBA. That some r-proteins may be limiting such that a $50 \%$ reduction in quantity may affect ribosome production in red cells, whereas for others a reduction of $50 \%$ may not be limiting, or may also be limiting in other tissues to the extent that it would interfere with embryogenesis, might explain why mutations in certain r-proteins account more frequently for DBA than others (Ellis and Massey 2006). There are alternative schemes that may underlie DBA pathogenesis. It is possible that certain cell types such as the developing red cell may be more sensitive to an imbalance in ribosome subunit production, and this may be more crucial in cells producing ribosomes at a high rate. In our HeLa cell model, the overproduction/degradation mechanism ensures that r-proteins not incorporated into ribosome subunits do not accumulate, but it is not clear whether this surveillance mechanism is present in the maturing red cell. Furthermore, there does not appear to be a mechanism for ensuring that large or small subunits do not accumulate in the absence of the other subunit.

In summary, our results support the notion that a failure in the production of ribosomes is the factor that triggers the process leading to the red cell aplasia characteristic of DBA. Presumably, any r-protein produced in limiting quantities and whose haploinsufficiency is not lethal in the embryo would be a candidate. Whether the crude number of ribosomes or the disruption of the nucleolar structure causing nucleolar stress and the activation of p53 are keys to pathogenesis in DBA is subject to our future investigations.

\section{MATERIALS AND METHODS}

\section{Cell culture}

HeLa cells were cultured in Dulbecco's modified Eagle's medium containing $15 \%$ fetal bovine serum, antibiotics (100 $\mu \mathrm{g}$ of penicillin and $50 \mu \mathrm{g}$ of streptomycin sulfate $/ \mathrm{mL}$ ), and $2 \mathrm{mM}$ glutamine at $37^{\circ} \mathrm{C}, 5 \% \mathrm{CO}_{2}$.

\section{RNA preparation}

Total RNA was extracted using Trizol (Invitrogen) following the manufacturer's instructions. Nuclear and cytoplasmic fractions were prepared using Cell fractionation buffer (Ambion), and then nuclear or cytoplasmic RNA was extracted from each fraction with Trizol.

\section{Oligonucleotides}

The oligonucleotide sequences complementary to the known human rDNA used in this paper were:

(Probe i) 20-ITS1: 5' -CCTCGCCCTCCGGGCTCCGTTAATTGA TC-3' (Rouquette et al. 2005); and

(Probe f) 15-ITS2: 5'-CGCACCCCGAGGAGCCCGGAGGCACC CCCGG-3' (Hadjiolova et al. 1993).
Complementary DNA was synthesized using SuperScript III reverse transcriptase (Invitrogen) following the manufacturer's instructions. The following primers were used for PCR:

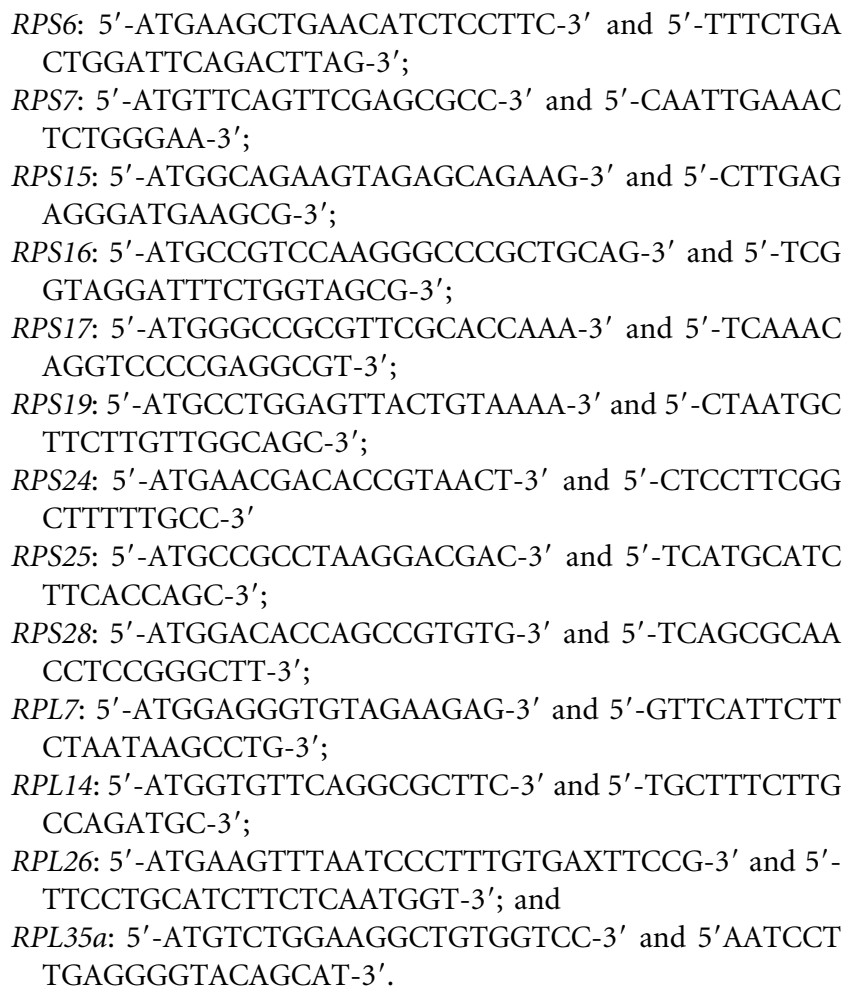

The first strand cDNA was synthesized by RT-PCR from total RNA using the SuperScript First-Strand Synthesis System (Invitrogen). After synthesis, target cDNA was amplified with specific primers by PCR with Platinum Taq DNA polymerase high fidelity (Invitrogen) for 35 cycles under the following conditions: $15 \mathrm{sec}, 94^{\circ} \mathrm{C}$; $30 \mathrm{sec}, 55^{\circ} \mathrm{C}$; and $60 \mathrm{sec}, 68^{\circ} \mathrm{C}$. PCR products were resolved by electrophoresis on $1 \%$ agarose.

\section{rRNA analysis}

Pre-rRNA analysis by Northern blotting was adapted from Hadjiolova et al. (1993) using synthetic oligonucleotide DNA and cDNA as probes. RNA $(10 \mu \mathrm{g})$ was electrophoresed in $1.25 \%$ $(\mathrm{w} / \mathrm{v})$ agarose-formaldehyde gels and blotted to Hybond- $\mathrm{N}^{+}$ membranes (GE Healthcare) overnight. Oligonucleotides were end-labeled with $\left[\gamma^{32} \mathrm{P}\right] \mathrm{ATP}$ and $\mathrm{T} 4$ polynucleotide kinase (Fisher), and cDNA probes were labeled with $\left[{ }^{32} \mathrm{P}\right] \mathrm{dCTP}$ using the Rediprime II random prime labeling system (Amersham Biosciences).

Membranes were hybridized overnight in hybridization buffer $(0.75 \mathrm{M} \mathrm{NaCl}, 0.075 \mathrm{M} \mathrm{Na}$ citrate $\mathrm{pH} 7.0,1 \times$ Denhardt's solution, $150 \mu \mathrm{g} / \mathrm{mL}$ tRNA) and 1\% SDS (when oligonucleotide probes were used), or $0.25 \mathrm{M} \mathrm{Na}$ /phosphate buffer, $1.0 \mathrm{~g} / \mathrm{L}$ BSA, and 7\% SDS (when cDNA probes were used). Temperature of hybridization was $55^{\circ} \mathrm{C}$ (probe i) and $65^{\circ} \mathrm{C}$ (probe $\mathrm{f}$ and cDNA probes for all different RPSs, RPLs, and $\beta$-actin). Washing conditions included $3 \times$ SSC, $0.1 \%$ SDS for $15 \mathrm{~min} ; 2 \times$ SSC, $0.1 \%$ SDS for $30 \mathrm{~min}$; and $0.2 \times$ SSC, $0.1 \%$ SDS for $30 \mathrm{~min}$ at $55^{\circ} \mathrm{C}$ or $65^{\circ} \mathrm{C}$ (for oligonucleotide probes $\mathrm{i}$ and $\mathrm{f}$, respectively), or $3 \times \mathrm{SSC}$, 
$0.3 \%$ SDS for $15 \mathrm{~min} ; 2 \times$ SSC, $0.3 \%$ SDS for $30 \mathrm{~min}$; and $0.2 \times$ SSC, $0.3 \%$ SDS for $45 \mathrm{~min}$ at $65^{\circ} \mathrm{C}$ (for cDNA probes). Membranes were both exposed to a storage phosphor screen (GE Healthcare) for further analysis using a phosphor imager (Typhoon trio, GE Healthcare) and X-ray film.

\section{Labeling of rRNA}

Cells were seeded in 12-well plates at $5 \times 10^{6}$ cells per well and pre-incubated for $45 \mathrm{~min}$ in methionine-free medium and then incubated for $30 \mathrm{~min}$ with $50 \mu \mathrm{Ci} \mathrm{L}-\left[\right.$ methyl $\left.{ }^{3} \mathrm{H}\right]$ methionine. Cells were then chased in nonradioactive medium containing $15 \mu \mathrm{g} / \mathrm{mL}$ methionine for $0,30,60$, and $120 \mathrm{~min}$, after which total RNA was isolated using Trizol (Invitrogen) and label incorporation for each sample was measured by scintillation counting. An equal number of counts were loaded in each lane of a $1.25 \%$ agarose-formaldehyde gel and then transferred to Hybond- ${ }^{+}$(GE Healthcare). Membranes were exposed to Xray film.

\section{Antibodies}

Anti-peptide RPS rabbit antibodies were generated from purified synthetic peptides obtained from Biomolecules Midwest, Inc..Three versions of each peptide were synthesized (native, $\mathrm{N}$-terminal cysteine, and N-terminal long-chain-biotin) and a KLH-peptide was used to immunize two rabbits with the resulting antiserum purified over a peptide-affinity column (Idol et al. 2007). The peptides corresponding to human RPS sequences were:

$\mathrm{K}_{7}$ IVKPNGEKPDEFESG $_{22}$ (RPS7);

$\mathrm{N}_{74}$ LIKVDDNKKLGEWV $_{88}$ (RPS12);

$\mathrm{A}_{1}$ EVEQKKKRTFRKFTY ${ }_{16}$ (RPS15);

$\mathrm{T}_{102}$ SRKQRKERKNRMKKVRGT 120 (RPS24); and

$\mathrm{K}_{33} \mathrm{KWSKGKVRDKLNNLVLFD}_{51}$ (RPS25).

Commercially available rabbit polyclonal antibodies against RPS6, RPL7, and RPL26 (Bethyl Laboratories) and RPS16 (GeneTX, Inc.) were obtained and used following the manufacturers' protocols. Rabbit polyclonal anti-GAPDH (Abcam) was used as a loading control.

\section{Sucrose gradient centrifugation}

Cells were washed in ice-cold PBS and incubated with $100 \mu \mathrm{g} / \mathrm{mL}$ cycloheximide in $\mathrm{PBS}$ for $10 \mathrm{~min}$ at $4^{\circ} \mathrm{C}$ prior to lysis. All subsequent steps were performed on ice. Cells were resuspended in hypotonic buffer $\left(1.5 \mathrm{mM} \mathrm{KCl}, 2.5 \mathrm{mM} \mathrm{MgCl}_{2}\right.$, and $5.0 \mathrm{mM}$ Tris- $\mathrm{Cl}$ at $\mathrm{pH}$ 7.4) followed by the addition of 80 units of RNase inhibitor (Invitrogen). Hypotonic lysis buffer (1.5 mM KCl, 2.5

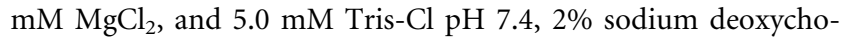
late, $2 \%$ Triton X-100, and $2.5 \mathrm{mM} \mathrm{DTT}$ ) were added and cells were gently homogenized with 10 strokes of a Dounce homogenizer. Cell lysates were centrifuged at $8000 \mathrm{~g}$ for $10 \mathrm{~min}$ at $4^{\circ} \mathrm{C}$ and the supernatant was adjusted to $2 \mathrm{mg} / \mathrm{mL}$ heparin. Lysates were stored at $-80^{\circ} \mathrm{C}$. Linear $10 \%-45 \%$ sucrose gradients $(80 \mathrm{mM}$ $\mathrm{NaCl}, 5 \mathrm{mM} \mathrm{MgCl}, 20 \mathrm{mM}$ Tris-Cl at $\mathrm{pH} 7.4$, and $1 \mathrm{mM} \mathrm{DTT}$ ) were poured using a Gradient Master (BioComp). Gradients were centrifuged at $38,000 \mathrm{rpm}$ for $3 \mathrm{~h}$ at $4^{\circ} \mathrm{C}$ and analyzed with an ISCO fractionator (ISCO).

\section{SIRNA}

A 21-bp siRNA targeting RPS19 was synthesized, annealed, and purified (Ambion): 5'-GAUGGCGGCCGCAAACUGUCA-3' (sense) and 5'-UCAGUUUGCGGCCGCCAUCTT-3' (antisense), named RPS19 siRNA \#2. One additional siRNA targeting RPS19 was obtained from Ambion (siRNA ID\# 2801). The following siRNAs were purchased from Ambion to target ribosomal proteins of interest:

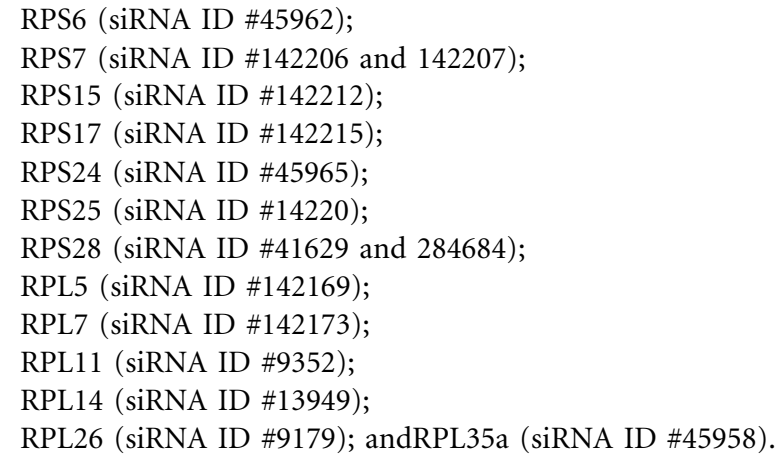

Silencer negative control \#1 (Ambion) was used as a negative control, and Silencer GAPDH (Ambion) was used as a positive control. Cells were transfected with siPORT NeoFX (Ambion) according to manufacturer's protocols using $30 \mathrm{nM}$ siRNA per well.

\section{Western blots}

Total cell extracts were made using Cellytic Reagent (Sigma) supplemented with a protease inhibitor cocktail (Roche), and protein concentration was determined by a modified Bradford assay (Bio-Rad). Proteins were separated on a $15 \%$ SDS-PAGE gel and transferred to Hybond nitrocellulose (GE Healthcare). Membranes were blocked overnight at $4^{\circ} \mathrm{C}$ in Odyssey blocking buffer (LI-COR). Membranes were incubated for $1 \mathrm{~h}$ at room temperature with primary antibodies in Odyssey blocking buffer containing $0.05 \%$ Tween-20, and washed three times with PBST. The secondary antibody, either goat anti-rabbit IRDYE 680 (LI-COR) or goat anti-mouse IRDYE 680 (LI-COR), was added to Odyssey blocking buffer (LI-COR) containing $0.05 \%$ Tween-20, and membranes were incubated for $1 \mathrm{~h}$ at room temperature. Membranes were washed twice with PBST, rinsed with PBS, and signals were detected with the Odyssey (LI-COR). All signal quantitation was performed with the Odyssey (LI-COR).

\section{ACKNOWLEDGMENTS}

This work was supported by NIH DK075443 (to M.B.), CA106995 (to P.J.M.), and the Daniella Maria Arturi Foundation. We thank Mary Jane Eichenseer for antibody purification, and an anonymous reviewer for helpful suggestions. We thank Robert Arceci and Hannah Gazda for permission to quote unpublished data.

Received April 10, 2008; accepted June 6, 2008. 


\section{REFERENCES}

Choesmel, V., Bacqueville, D., Rouquette, J., Noaillac-Depeyre, J., Fribourg, S., Cretien, A., Leblanc, T., Tchernia, G., Da Costa, L., and Gleizes, P.E. 2007. Impaired ribosome biogenesis in DiamondBlackfan anemia. Blood 109: 1275-1283.

Choesmel, V., Fribourg, S., Aguissa-Toure, A.H., Pinaud, N., Legrand, P., Gazda, H.T., and Gleizes, P.E. 2008. Mutation of ribosomal protein RPS24 in Diamond-Blackfan anemia results in a ribosome biogenesis disorder. Hum. Mol. Genet. 17: 12531263.

Cmejla, R., Cmejlova, J., Handrkova, H., Petrak, J., and Pospisilova, D. 2007. Ribosomal protein S17 gene (RPS17) is mutated in Diamond-Blackfan anemia. Hum. Mutat. 28: 11781182.

Draptchinskaia, N., Gustavsson, P., Andersson, B., Pettersson, M., Willig, T.N., Dianzani, I., Ball, S., Tchernia, G., Klar, J., Matsson, H., et al. 1999. The gene encoding ribosomal protein S19 is mutated in Diamond-Blackfan anemia. Nat. Genet. 21: 169175.

Ebert, B.L., Lee, M.M., Pretz, J.L., Subramanian, A., Mak, R., Golub, T.R., and Sieff, C.A. 2005. An RNA interference model of RPS19 deficiency in Diamond-Blackfan anemia recapitulates defective hematopoiesis and rescue by dexamethasone: Identification of dexamethasone-responsive genes by microarray. Blood 105: $4620-4626$.

Ellis, S.R. and Massey, A.T. 2006. Diamond Blackfan anemia: A paradigm for a ribosome-based disease. Med. Hypotheses 66: 643648.

Farrar, J.E., Nater, M., Caywood, E., McDevitt, M.A., Kowalski, J., Takemoto, C.M., Talbot, C.C.J., Meltzer, P., Esposito, D., Beggs, A.H., et al. 2008. Abnormalities of the large ribosomal subunit protein, Rpl35A, in Diamond-Blackfan Anemia. Blood doi: 10.1182/blood-2008-02-140012.

Ferreira-Cerca, S., Poll, G., Kuhn, H., Neueder, A., Jakob, S., Tschochner, H., and Milkereit, P. 2007. Analysis of the in vivo assembly pathway of eukaryotic $40 \mathrm{~S}$ ribosomal proteins. Mol. Cell 28: $446-457$.

Flygare, J. and Karlsson, S. 2007. Diamond-Blackfan anemia: Erythropoiesis lost in translation. Blood 109: 3152-3154.

Flygare, J., Kiefer, T., Miyake, K., Utsugisawa, T., Hamaguchi, I., Da Costa, L., Richter, J., Davey, E.J., Matsson, H., Dahl, N., et al. 2005. Deficiency of ribosomal protein S19 in CD34+ cells generated by siRNA blocks erythroid development and mimics defects seen in Diamond-Blackfan anemia. Blood 105: 46274634.

Flygare, J., Aspesi, A., Bailey, J.C., Miyake, K., Caffrey, J.M., Karlsson, S., and Ellis, S.R. 2007. Human RPS19, the gene mutated in Diamond-Blackfan anemia, encodes a ribosomal protein required for the maturation of $40 \mathrm{~S}$ ribosomal subunits. Blood 109: $980-986$.

Gazda, H.T., Zhong, R., Long, L., Niewiadomska, E., Lipton, J.M., Ploszynska, A., Zaucha, J.M., Vlachos, A., Atsidaftos, E., Viskochil, D.H., et al. 2004. RNA and protein evidence for haplo-insufficiency in Diamond-Blackfan anaemia patients with RPS19 mutations. Br. J. Haematol. 127: 105-113.

Gazda, H.T., Grabowska, A., Merida-Long, L.B., Latawiec, E., Schneider, H.E., Lipton, J.M., Vlachos, A., Atsidaftos, E., Ball, S.E., Orfali, K.A., et al. 2006. Ribosomal protein S24 gene is mutated in Diamond-Blackfan anemia. Am. J. Hum. Genet. 79: $1110-1118$.

Hadjiolova, K.V., Nicoloso, M., Mazan, S., Hadjiolov, A.A., and Bachellerie, J.P. 1993. Alternative pre-rRNA processing pathways in human cells and their alteration by cycloheximide inhibition of protein synthesis. Eur. J. Biochem. 212: 211-215.

Helser, T.L., Baan, R.A., and Dahlberg, A.E. 1981. Characterization of a $40 \mathrm{~S}$ ribosomal subunit complex in polyribosomes of Saccharomyces cerevisiae treated with cycloheximide. Mol. Cell. Biol. 1: 5157.
Idol, R.A., Robledo, S., Du, H.Y., Crimmins, D.L., Wilson, D.B., Ladenson, J.H., Bessler, M., and Mason, P.J. 2007. Cells depleted for RPS19, a protein associated with Diamond Blackfan Anemia, show defects in $18 \mathrm{~S}$ ribosomal RNA synthesis and small ribosomal subunit production. Blood Cells Mol. Dis. 39: 35-43.

Lam, Y.W., Lamond, A.I., Mann, M., and Andersen, J.S. 2007. Analysis of nucleolar protein dynamics reveals the nuclear degradation of ribosomal proteins. Curr. Biol. 17: 749-760.

Leger-Silvestre, I., Milkereit, P., Ferreira-Cerca, S., Saveanu, C., Rousselle, J.C., Choesmel, V., Guinefoleau, C., Gas, N., and Gleizes, P.E. 2004. The ribosomal protein Rps15p is required for nuclear exit of the $40 \mathrm{~S}$ subunit precursors in yeast. EMBO J. 23: 2336-2347.

Leger-Silvestre, I., Caffrey, J.M., Dawaliby, R., Alvarez-Arias, D.A., Gas, N., Bertolone, S.J., Gleizes, P.E., and Ellis, S.R. 2005. Specific role for yeast homologs of the Diamond Blackfan Anemiaassociated Rps19 protein in ribosome synthesis. J. Biol. Chem. 280: $38177-38185$.

Lipton, J.M. 2006. Diamond Blackfan anemia: New paradigms for a "not so pure" inherited red cell aplasia. Semin. Hematol. 43: 167177.

Lohrum, M.A., Ludwig, R.L., Kubbutat, M.H., Hanlon, M., and Vousden, K.H. 2003. Regulation of HDM2 activity by the ribosomal protein L11. Cancer Cell 3: 577-587.

Marechal, V., Elenbaas, B., Piette, J., Nicolas, J.C., and Levine, A.J. 1994. The ribosomal L5 protein is associated with $\mathrm{mdm}-2$ and mdm-2-p53 complexes. Mol. Cell. Biol. 14: 7414-7420.

Matsson, H., Davey, E.J., Draptchinskaia, N., Hamaguchi, I., Ooka, A., Leveen, P., Forsberg, E., Karlsson, S., and Dahl, N. 2004. Targeted disruption of the ribosomal protein S19 gene is lethal prior to implantation. Mol. Cell. Biol. 24: 4032-4037.

Matsson, H., Davey, E.J., Frojmark, A.S., Miyake, K., Utsugisawa, T., Flygare, J., Zahou, E., Byman, I., Landin, B., Ronquist, G., et al. 2006. Erythropoiesis in the Rps19 disrupted mouse: Analysis of erythropoietin response and biochemical markers for Diamond-Blackfan anemia. Blood Cells Mol. Dis. 36: $259-264$.

Moritz, M., Paulovich, A.G., Tsay, Y.F., and Woolford Jr., J.L. 1990. Depletion of yeast ribosomal proteins L16 or rp59 disrupts ribosome assembly. J. Cell Biol. 111: 2261-2274.

Ohene-Abuakwa, Y., Orfali, K.A., Marius, C., and Ball, S.E. 2005. Two-phase culture in Diamond Blackfan anemia: Localization of erythroid defect. Blood 105: 838-846.

Rifkind, R.A., Danon, D., and Marks, P.A. 1964. Alterations in polyribosomes during erythroid cell maturation. J. Cell Biol. 22: 599-611.

Rosado, I.V., Kressler, D., and de la Cruz, J. 2007. Functional analysis of Saccharomyces cerevisiae ribosomal protein Rpl3p in ribosome synthesis. Nucleic Acids Res. 35: 4203-4213.

Rouquette, J., Choesmel, V., and Gleizes, P.E. 2005. Nuclear export and cytoplasmic processing of precursors to the $40 \mathrm{~S}$ ribosomal subunits in mammalian cells. EMBO J. 24: 28622872.

Steitz, T.A. and Moore, P.B. 2003. RNA, the first macromolecular catalyst: The ribosome is a ribozyme. Trends Biochem. Sci. 28: 411418.

van Beekvelt, C.A., de Graaff-Vincent, M., Faber, A.W., van't Riet, J., Venema, J., and Raue, H.A. 2001. All three functional domains of the large ribosomal subunit protein L25 are required for both early and late pre-rRNA processing steps in Saccharomyces cerevisiae. Nucleic Acids Res. 29: 5001-5008.

Warner, J.R. 1977. In the absence of ribosomal RNA synthesis, the ribosomal proteins of HeLa cells are synthesized normally and degraded rapidly. J. Mol. Biol. 115: 315-333.

Warner, J.R. 1979. Distribution of newly formed ribosomal proteins in HeLa cell fractions. J. Cell Biol. 80: 767-772.

Warner, J.R. 1999. The economics of ribosome biosynthesis in yeast. Trends Biochem. Sci. 24: 437-440. 
West, M., Hedges, J.B., Chen, A., and Johnson, A.W. 2005. Defining the order in which Nmd3p and Rpl10p load onto nascent $60 \mathrm{~S}$ ribosomal subunits. Mol. Cell. Biol. 25: 3802-3813.

Willig, T.N., Draptchinskaia, N., Dianzani, I., Ball, S., Niemeyer, C., Ramenghi, U., Orfali, K., Gustavsson, P., Garelli, E., Brusco, A., et al. 1999. Mutations in ribosomal protein S19 gene and Diamond Blackfan anemia: Wide variations in phenotypic expression. Blood 94: 4294-4306.

Wool, I.G. 1996. Extraribosomal functions of ribosomal proteins. Trends Biochem. Sci. 21: 164-165.
Zhang, Y., Wolf, G.W., Bhat, K., Jin, A., Allio, T., Burkhart, W.A., and Xiong, Y. 2003. Ribosomal protein L11 negatively regulates oncoprotein MDM2 and mediates a p53-dependent ribosomal-stress checkpoint pathway. Mol. Cell. Biol. 23: 89028912.

Zhang, J., Harnpicharnchai, P., Jakovljevic, J., Tang, L., Guo, Y., Oeffinger, M., Rout, M.P., Hiley, S.L., Hughes, T., and Woolford Jr., J.L. 2007. Assembly factors Rpf2 and Rrs1 recruit 5S rRNA and ribosomal proteins rpL5 and rpL11 into nascent ribosomes. Genes \& Dev. 21: 2580-2592. 

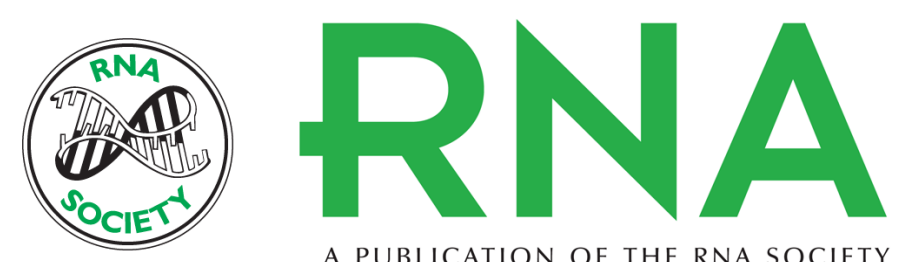

A PUBLICATION OF THE RNA SOCIETY

\section{The role of human ribosomal proteins in the maturation of rRNA and ribosome production}

Sara Robledo, Rachel A. Idol, Dan L. Crimmins, et al.

RNA 2008 14: 1918-1929 originally published online August 12, 2008

Access the most recent version at doi:10.1261/rna.1132008

$\begin{array}{ll}\text { References } & \begin{array}{l}\text { This article cites } 39 \text { articles, } 20 \text { of which can be accessed free at: } \\ \text { http://rnajournal.cshlp.org/content/14/9/1918.full.html\#ref-list-1 }\end{array}\end{array}$

License

Email Alerting Receive free email alerts when new articles cite this article - sign up in the box at the Service top right corner of the article or click here. 